\title{
Analisis Disiplin Kerja Dan Kontroling Kerja Terhadap Kinerja Pegawai Pada Dinas Pekerjaan Umum Dan Penataan Ruang (PUPR) Kabupaten Nganjuk
}

\author{
Luluk Listiana
}

Magister Manajemen Program Pascasarjana Universitas Islam Kadiri

\begin{abstract}
Abstrak
Capaian merefleksikan seberapa baik karyawan memenuhi kondisi-kondisi suatu pekerjaan. Untuk meningkatkan capaian karyawan tentang banyak faktor yang mempengaruhi, sebagai contoh pendidikan, disiplin bekerja, motivasi, lingkungan tentang pekerjaan kondusif yang mana dan sebagainya. Populasi di dalam riset ini apakah entire/all karyawan tentang pada Dinas Pekerjaan Umum dan Penataan Ruang (PUPR) Kabupaten Nganjuk yang berjumlah 77 orang-orang, sedang sampel di dalam riset ini yang adalah sebanyak 77 menjawab / orang-orang.. Teknik tentang data yang mengumpulkan di dalam riset ini adalah penggunaan metoda pengamatan, metoda dokumentasi, dan metoda kuesioner. Metoda meneliti data menggunakan analisa yang deskriptif tentang persentase, menguji aktivita s, menguji multikolinieritas, menguji heteroskedastisitas, dan meneliti menggandakan regresi linier. Karena pengujian hipotesis dengan test $\mathrm{t}($ menguji parsial), menguji $\mathrm{f}($ menguji simultan), dan koefisien determinasi $\left(\mathrm{R}^{2}\right)$.

Kesimpulan dari hasil penelitian ini adalah: (1) Terdapat pengaruh secara parsial antara disiplin kerja terhadap kinerja karyawan di Dinas Pekerjaan Umum dan Penataan Ruang (PUPR) Kabupaten Nganjuk. (2) Terdapat pengaruh secara parsial antara kontroling kerja terhadap kinerja karyawan di Dinas Pekerjaan Umum dan Penataan Ruang (PUPR) Kabupaten Nganjuk. (3) Terdapat pengaruh secara simultan antara disiplin kerja dan kontroling kerja terhadap kinerja karyawan di Dinas Pekerjaan Umum dan Penataan Ruang (PUPR) Kabupaten Nganjuk, sedangkan sisanya dipengaruhi oleh faktor lain yang tidak dikaji dalam penelitian ini. Perbedaan penelitian ini dengan penelitian sebelumnya adalah mempertimbangkan variabel-variabel lain di luar variabel yang sudah masuk dalam penelitian sebelumnya, yaitu variabel disiplin kerja, kontroling kerja, dan kinerja karyawan yang saling berkaitan. Kata Kunci: Disiplin kerja, kontroling, kinerja.
\end{abstract}

\begin{abstract}
Performance reflection how well employees fulfill the conditions a work. To increase employees performance a lot of factor influencing, for example education, discipline work the, motivation, environmental job which kondusif etcetera. Population in this research entire/ all employees on duty Public Work and Space Settlement (PUPR) of Regency Nganjuk amounting to 77 people, while sampel in this research that is as much 77 people/responder. Technique data collecting in this research by using observation method, documentation method, and method kuesioner. Method analyse the data use the descriptive analysis percentage, test the normalitas, test the multikolinieritas, test the heteroskedastisitas, and analyse the doubled linear regresi. For the examination of hypothesis with the test $t$ (test the parsial), test the $f$ (test the simultan), and coefficient determinasi (R2).

Conclusion from this research result is: (1) there are influences by parsial between discipline work to employee's performance on duty Public Work and Space Settlement (PUPR) of Regency Nganjuk. (2) There are influences by parsial between controling work to employee's performance on duty Public Work and Space Settlement (PUPR) of Regency Nganjuk. (3) There are influence by simultan between discipline work and kontroling work to employees performance On duty Public Work and Space Settlement (PUPR) of Regency Nganjuk, while the rest influenced by other; dissimilar factor which is not studied in this research. This Research difference with the previous research consider the other; dissimilar variable outside variable enter in previous research, that is discipline variable work the, controling work, and employees performance which each other interconnected.

Keyword: Discipline works the, controling, performance.
\end{abstract}




\section{Pendahuluan}

Kinerja adalah hasil kerja secara kualitas dan kuantitas yang dicapai seorang pegawai dalam melaksanakan tugasnya sesuai dengan tanggung jawab yang diberikan kepadanya (Mangkunegara, 2014: 76). Kinerja dikatakan penting dalam kemajuan sebuah instansi. Dikatakan penting dikarenakan kinerja merupakan indikator instansi dalam menilai karyawan selama bekerja di instansi tersebut. Kinerja yang bagus mampu membawa instansi kearah tujuan instansi ataupun cita-cita instansi sedangkan kinerja yang buruk menghambat pencapaian cita-cita instansi. Salah satu kondsi dimana kinerja pegawai tersebut kurang salah satunya adalah keterlambatan masuk kerja ataupun jalanjalan selama jam kerja, fenomena ini seringkali terlihat dalam berita di media elektronik televisi. Kinerja dipengaruhi oleh berbagai faktor diantaranya adalah disiplin kerja, komitmen organisasi, dan lingkungan kerja.

Disiplin kerja menurut Hasibuan (2015: 122) adalah kesadaran dan kesediaan seseorang menaati peraturan instansi dan norma-norma sosial yang berlaku. Setiap lembaga ataupun instansi pasti memiliki peraturan yang wajib dipatuhi oleh setiap pegawainya. Peraturan dibuat guna mengatur segala tata tertib di instansi. Seperti halnya apa yang harus dilakukan serta apa yang tidak boleh dilakukan seperti halnya etika dalam bekerja dalam sebuah instansi. Fenomena disiplin kerja terlihat dari pegawai masuk hingga pegawai selesai dalam bekerja (pulang kerja) harus sesuai dengan jam yang dijadikan patokan selama bekerja dalam instansi. Dengan adanya kedisiplinan maka dipastikan bahwa kinerja juga dalam kondisi yang sesuai dengan keinginan instansi.

Di dalam penelitian ini hanya difokuskan pada faktor disiplin dan kontroling kerja. Secara teori jika disiplin dan kontroling kerja dapat berjalan dengan baik dan maksimal maka kinerja yang akan dihasilkan karyawan akan baik pula. Kinerja dapat diukur dari sikap disiplin yang dimiliki masing-masing karyawan. Disiplin kerja yang tinggi secara otomatis akan menghasilkan kinerja yang baik pula. Disiplin kerja merupakan kegiatan manajemen untuk menjalankan standar-standar organisasional (Handoko, 2016: 208). Setiap karyawan harus mempunyai kesadaran secara internal akan kedisiplinan terhadap pekerjaannya sebab rata-rata individu lebih memahami apa yang diharapkan dalam pekerjaannya.

Faktor lain yang mempengaruhi kedisiplinan kerja pegawai yaitu kontroling kerja organisasi. Kontroling kerja organisasi menunjukkan suatu daya yang muncul dari diri seseorang dalam mengidentifikasikan keterlibatan sebagai bagian dari organisasi. Kontroling kerja dibangun atas dasar kepercayaan pegawai atas nilai-nilai organisasi, kerelaan pegawai membantu mewujudkan tujuan organisasi dan loyalitas untuk tetap menjadi anggota organisasi. Oleh karena itu kontroling kerja organisasi akan memunculkan rasa ikut memiliki (sense of belonging) bagi pegawai terhadap organisasi.

Pendisiplinan karyawan bertujuan untuk melatih dan memperbaiki sikap serta perilaku karyawan sehingga karyawan secara suka rela melaksanakan kewajiban pekerjaannya. Kedisiplinan tidak hanya diterapkan oleh tiap individu tetapi juga melibatkan seluruh karyawan yang ada di dalam instansi tersebut untuk membantu instansi mencapai kesuksesan. Oleh sebab itu, kedisiplinan karyawan merupakan proses berkelanjutan di mana seluruh individu berkaitan erat dengan instansi untuk kepentingan instansi.

Berdasarkan konsep teoritik dan penelitian terdahulu di atas, maka dapat dirumuskan masalah penelitian sebagai berikut:

a. Bagaimana pengaruh disiplin kerja dan kontroling kerja secara simultan terhadap kinerja karyawan pada Dinas Pekerjaan Umum dan Penataan Ruang (PUPR) Kabupaten Nganjuk?

b. Bagaimana pengaruh disiplin kerja terhadap kinerja karyawan pada Dinas Pekerjaan Umum dan Penataan Ruang (PUPR) Kabupaten Nganjuk?

c. Bagaimana pengaruh kontroling kerja terhadap kinerja karyawan pada Dinas Pekerjaan Umum dan Penataan Ruang (PUPR) Kabupaten Nganjuk?

Disiplin kerja merupakan praktek secara nyata dari para pegawai terhadap perangkat peraturan yang terdapat dalam suatu organisasi. Disiplin tidak hanya dalam bentuk ketaatan saja melainkan juga tanggung jawab yang diberikan oleh instansi, 
berdasarkan pada hal tersebut diharapkan efektifitas pegawai akan meningkat dan bersikap serta bertingkah laku disiplin.

Kontroling kerja merupakan suatu usaha sistematik untuk menentukan standar pelaksanaan dan tujuan perencanaan serta untuk menjamin agar semua pekerjaan dilaksanakan sesuai dengan rencana yang telah ditentukan.

Kinerja pegawai adalah hasil dari proses pekerjaan tertentu secara berencana pada waktu dan tempat dari karyawan serta organisasi bersangkutan menurut Mangkunegara (2016: 153). Menurut Stolovitch and Keeps (dalam blog Mangkunegara) kinerja adalah seperangkat hasil yang dicapai dan merujuk pada tindakan pencapaian serta pelaksanaan sesuatu pekerjaan yang diminta. Kinerja karyawan adalah hasil kerja yang dicapai oleh karyawan sesuai dengan wewenang dan tanggung jawabnya dalam melaksanakan tugas-tugas yang diberikan kepadanya, di mana suatu target kerja dapat diselesaikan pada waktu yang tepat atau tidak melampaui batas waktu yang disediakan sehingga tujuan organisasi akan tercapai sesuai dengan moral maupun etika.

\section{Metode Penelitian}

Di dalam riset ini apakah jenis riset menggunakan apakah eksplanatory, yang itu adalah riset yang mana mengarahkan ke untuk menguji teori atau hipotesis menggunakan untuk memperkuat atau genap sampah hipotesis atau teori tentang hasil riset ke sana apakah. riset Eksplanatory mengarahkan ke untuk menjelaskan dua atau lebih variabel.

Populasi dalam penelitian ini adalah seluruh karyawan pada Dinas Pekerjaan Umum dan Penataan Ruang (PUPR) Kabupaten Nganjuk yang berjumlah 77 orang. Sedangkan sampel dalam penelitian ini sebanyak 77 orang/responden..

Penelitain ini menggunakan dua variabel, variabel bebas dan variabel terikat yaitu: variabel bebas/variabel independen (X) dan variabel terikat/variabel dependen (Y). Dalam penelitian ini yang menjadi variabel bebas $(\mathrm{X})$ adalah: disiplin kerja $\left(\mathrm{X}_{1}\right)$ dan kontroling kerja $\left(\mathrm{X}_{2}\right)$. Sedangkan yang menjadi variabel terikat adalah kinerja karyawan $(\mathrm{Y})$.
Indikator dari kinerja karyawan menggunakan teori dari Robert L. Mathis \& John H. Jackson (2016: 378) antara lain:

a. Kualitas hasil pekerjaan, yaitu menilai baik tidaknya hasil pekerjaan karyawan.

b. Kuantitas pekerjaan, merupakan jumlah yang dihasilkan dinyatakan dalam istilah seperti jumlah unit, jumlah siklus aktivitas yang diselesaikan.

c. Ketepatan waktu, dalam menyelesaikan tugas para karyawan bukan hanya dituntut untuk cepat menyelesaikan pekerjaannya namun juga harus tepat atau sesuai dengan harapan atasan.

d. Kehadiran, dengan kehadiran menunjukkan semangat kerja yang dimiliki oleh karyawan.

e. Kemampuan bekerjasama baik dengan rekan satu bagian maupun bagian lain.

Sedangkan variabel bebas dinyatakan dengan simbol $\mathrm{X}$, yaitu terdiri dari disiplin kerja dan kontroling kerja.

Disiplin kerja $\left(\mathrm{X}_{1}\right)$

Dalam penelitian ini yang dimaksud dengan disiplin kerja adalah kesadaran dan kesediaan seseorang mentaati semua peraturan perusahaan dan norma-norma sosial yang berlaku. Indikator dari disiplin kerja menggunakan teori dari Abdurrahmat (2016: 173) antara lain:

1) Balas jasa

Balas jasa mempengaruhi kepuasan dan kecintaan karyawan terhadap pekerjaannya. Jika kecintaan karyawan terhadap pekerjaannya semakin baik, maka kedisiplinannya pun akan semakin baik pula.

2) Keadilan

Keadilan yang dijadikan dasar kebijaksanaan dalam pemberian balas jasa (pengakuan) atau hukuman akan merangsang terciptanya kedisiplinan karyawan yang baik.

3) Waskat

Waskat ( kontroling padu) adalah tindakan riil dan efektif untuk mencegah/untuk mengetahui kekeliruan, mengoreksi kekeliruan, memelihara disiplin meningkatkan tenaga kerja kapasitas dan juga menciptakan sistem yang internal tentang kendali terbaik di dalam pendukung untuk ada target perusahaan.

4) Sanksi hukuman

Dengan keberadaan sanksi penghukuman karenanya akan memberi kesan enggan untuk indisipliner bagi semua 
karyawan, sebab mereka tidak ingin menjamin resiko.

5) Ketegasan

Kepala yang mana berani bertindak padu di dalam penghukuman yang memberi untuk tindakan indisipliner karyawan akan jadi terhormat dan diakui kepemimpinan nya karyawan, yang itu kepala jalan/cara akan mampu memelihara karyawan disiplin di dalam perusahaan.

Kontroling kerja $\left(\mathrm{X}_{2}\right)$

Di dalam riset ini adalah seperti kontroling pekerjaan adalah memproses dari entire/all aktivitas organisatoris menggunakan lebih guaranting bahwa semua pekerjaan yang mana adalah menjadi ketika menurut merencanakan ditentukan sebelumnya. Indikator dari kontroling pekerjaan untuk menggunakan teori dari Handoko (2016: 363) sebagai contoh:

1) Penetapan standar

Standard yang yang menetapkan fungsi untuk memudahkan manajer untuk komunikasi pelaksanaan pekerjaan yang diharapkan ke semua bawahan; subordinat secara lebih jelas dan other;dissimilar melangkah dalam proses perencanaan dapat ditangani secara efektif.

2) Penentuan pengukuran/penilaian pekerjaan

$\begin{array}{rrrr} & \text { Penetapan } & \text { standar akan sia-sia } \\ \text { apabila } & \text { tidak } & \text { ada } & \text { penentuan }\end{array}$ pengukuran/penilaian pekerjaan yang tepat. Pengukuran ini sebaiknya mudah dilaksanakan dan tidak mahal, serta dapat diterangkan kepada karyawan.

3) Pengukuran pelaksanaan pekerjaan

Pelaksanaan pengukuran sebagai proses yang mana berulang-kali dan yang berlanjut. ke sana apakah berbagai cara untuk pengukuran pelaksanaan, yang itu adalah pengamatan, yang baik lisan melaporkan dan juga menulis, pemeriksaan dan metoda otomatis, pengujian (tes) atau dengan masukan itu sampel.

4) Perbandingan pelaksanaan dengan standar dan analisis penyimpangan

Tahap kritis dari proses yang kontroling apakah eksekusi nyata memperbandingkan dengan pelaksanaan merencanakan atau standard yang mana telah ditetapkan. Walaupun tahap ini paling mudah, tetapi kompleksitas dapat terjadi pada pada waktu menginterpretasikan keberadaan penyimpangan.

5) Perbaikan atas penyimpangan

Bila hasil meneliti untuk menunjukkan keberadaan koreksi, tindakan ini harus di dalam pengambilan. Tindakan korektif dapat diambil dalam berbagai format. Mungkin standard di dalam mengubah, pelaksanaan yang improve atau kedua-duanya pada waktu yang sama.

Adapun teknik pengumpulan data dalam penelitian ini adalah dengan menggunakan metode:

Observasi

Dalam penelitian ini observasi dilakukan dengan mengamati disiplin kerja dan kontroling kerja serta kinerja karyawan Dinas Pekerjaan Umum dan Penataan Ruang (PUPR) Kabupaten Nganjuk.

Dokumentasi

Data yang didapat adalah data volume produksi, data pegawai dan jumlahnya, gambaran umum, struktur organisasi dan uraian tugas jabatan, aktivitas produksi dan pemasaran pada Dinas Pekerjaan Umum dan Penataan Ruang (PUPR) Kabupaten Nganjuk.

Kuesioner

Jenis kuesioner yang digunakan adalah kuesioner tertutup, yaitu kuesioner yang sudah disediakan jawabannya sehingga responden tinggal memilih jawaban yang tersedia.

Dalam penelitian ini metode analisis data yang digunakan adalah:

Analisis Regresi Linier Berganda

Dalam penelitian ini hanya terdiri dari tiga variabel yaitu satu variabel kinerja karyawan $(\mathrm{Y})$, dua variabel disiplin kerja dan kontroling kerja $\left(\mathrm{X}_{1}\right.$ dan $\left.\mathrm{X}_{2}\right)$, sehingga persamaan regresi dengan menggunakan rumus Sugiyono (2014: 275) adalah:

$\mathbf{Y}=\mathbf{a}+\mathrm{b}_{1} \mathbf{X}_{1}+\mathrm{b}_{2} \mathbf{X}_{2}+\mathrm{e}$

Pengujian Hipotesis Penelitian

Uji t (Uji Parsial)

Cara pengujiannya dengan bantuan SPSS. Kaidah dalam pengambilan keputusan dalam uji t adalah:

a) Jika probalitas $>0,05$ maka Ho diterima (variance sama)

b) Jika probalitas $<0,05$ maka Ho ditolak (variance berbeda)

Uji F (Uji Simultan) 
Uji simultan (uji F) ini digunakan untuk menguji pengaruh variabel kinerja karyawan terhadap variabel disiplin kerja dan variabel kontroling kerja secara simultan dengan tingkat signifikan yang digunakan sebesar $\alpha=5 \%$ dan df (k:n-k-1). Kaidah pengambilan keputusan dalam uji $\mathrm{F}$ dengan menggunakan SPSS adalah:

a. Jika probabilitas $>0,05$, maka Ho diterima.

b. Jika probabilitas $<0,05$, maka Ho ditolak.

Koefisien Determinasi $\left(\mathrm{R}^{2}\right)$

$$
\text { Koefisien Determinasi }
$$

digunakan untuk mengukur tingkat ketepatan atau kecocokan goodness of fit) dari regresi linier berganda. Jika $\mathrm{R}^{2}=1$, berarti besarnya presentase sumbangan $\mathrm{X}$ terhadap variasi (naik turunnya) Y secara bersama-sama adalah $100 \%$. Rumus dari koefisien determinasi sebagai berikut:

$\mathrm{R}^{2}=\mathrm{r}^{2} \times 100 \%$

\section{Hasil Penelitian}

Distribusi Variabel

Kinerja Karyawan $(\mathrm{Y})$

Hasil penelitian tentang kinerja karyawan Dinas Pekerjaan Umum dan Penataan Ruang (PUPR) Kabupaten Nganjuk pada lampiran diperoleh skor total sebesar 4020, berdasarkan kategori kinerja karyawan pada tabel 4.1 termasuk kategori tinggi. Berdasarkan data yang diperoleh, skor total $=$ 4020, skor maksimal $=5005$, jadi Deskriptif Persentase (DP) $=$ skor total: skor maksimal $\mathrm{x}$ $100 \%=4020: 5005 \times 100 \%=80,32 \%$. Hasil penelitian tentang kinerja karyawan Dinas Pekerjaan Umum dan Penataan Ruang (PUPR) Kabupaten Nganjuk pada perhitungan di atas diperoleh hasil 80,32\% dan berdasarkan kategori variabel kinerja karyawan termasuk kategori tinggi.

Disiplin Kerja $\left(\mathrm{X}_{1}\right)$

Hasil penelitian tentang disiplin kerja Dinas Pekerjaan Umum dan Penataan Ruang (PUPR) Kabupaten Nganjuk pada lampiran diperoleh skor total sebesar 3760, berdasarkan kategori disiplin kerja pada tabel di atas termasuk kategori tinggi. Berdasarkan data yang diperoleh, skor total $=3760$, skor maksimal $=5005$, jadi Deskriptif Persentase $(D P)=$ skor total: skor maksimal $\times 100 \%=$ 3760: $5005 \times 100 \%=75,12 \%$. Hasil penelitian tentang disiplin kerja Dinas Pekerjaan Umum dan Penataan Ruang
(PUPR) Kabupaten Nganjuk pada perhitungan di atas diperoleh $75,12 \%$ dan berdasarkan kategori variabel disiplin kerja termasuk kategori tinggi.

Kontroling Kerja $\left(\mathrm{X}_{2}\right)$

Hasil penelitian tentang kontroling kerja Dinas Pekerjaan Umum dan Penataan Ruang (PUPR) Kabupaten Nganjuk pada lampiran diperoleh skor total sebesar 3600, berdasarkan kategori kontroling kerja pada tabel di atas termasuk kategori tinggi. Berdasarkan data yang diperoleh, skor total $=$ 3600 , skor maksimal $=4620$, jadi Deskriptif Persentase (DP) $=$ skor total: skor maksimal $\mathrm{x}$ $100 \%=3600: 4620 \times 100 \%=77,92 \%$. Hasil penelitian tentang kontroling kerja di Dinas Pekerjaan Umum dan Penataan Ruang (PUPR) Kabupaten Nganjuk pada perhitungan di atas diperoleh $77,92 \%$ dan berdasarkan kategori variabel kontroling kerja termasuk kategori tinggi.

Analisis Regresi Linier Berganda

Model persamaan regresi yang dapat dituliskan dari hasil tersebut dalam bentuk persamaan regresi standardized adalah sebagai berikut:

$$
\begin{aligned}
& \mathrm{Y}=\mathrm{a}+\mathrm{bX} 1+\mathrm{bX} 2+\mathrm{bX} 3+\mathrm{e} \\
& \mathrm{Y}=8,592+0,244 \mathrm{X}_{1}+0,678 \mathrm{X}_{2}
\end{aligned}
$$

Persamaan di atas mengandung makna:

a) Konstanta sebesar 8,592. Jika variabel disiplin kerja dan kontroling kerja dengan nol maka besarnya kinerja karyawan adalah 8,592.

b) Nilai koefisien disiplin kerja sebesar 0,244 menyatakan bahwa setiap terjadi kenaikan 1 skor untuk disiplin kerja akan diikuti terjadi kenaikan kinerja karyawan sebesar 0,244 jika nilai dari variabel lain tetap.

c) Nilai koefisien kontroling kerja menunjukkan angka sebesar 0,678 menyatakan bahwa apabila terjadi kenaikan 1 skor untuk kontroling kerja akan diikuti dengan terjadi kenaikan kinerja karyawan sebesar 0,678 jika nilai dari variabel lain tetap.

\section{Uji Hipotesis}

Uji F (Uji Simultan)

Berdasarkan hasil uji simultan (uji F) diperoleh $\mathrm{F}$ hitung $=71,494$ dengan nilai signifikansi 0,000 karena nilai signifikansi jauh lebih kecil dari 0,05 maka Ho ditolak, hal ini menunjukkan bahwa Ha yang berbunyi ada 
pengaruh disiplin kerja dan kontroling kerja terhadap kinerja karyawan Dinas Pekerjaan Umum dan Penataan Ruang (PUPR) Kabupaten Nganjuk Ha diterima.

Uji t (Uji Parsial)

Berdasarkan hasil uji parsial (uji t) untuk variabel pekerjaan disiplin memperoleh $\mathrm{t}$ sepadan dengan 2,680 dengan nilai itu signifikansi 0,009 sebab nilai signifikansi jauh lebih kecil dari 0,05 karenanya Ho menolak, perihal ini menunjukkan bahwa $\mathrm{Ha}$ yang membunyikan ke sana adalah pengaruh disiplin bekerja ke capaian karyawan Dinas Pekerjaan Umum dan Penataan Ruang (PUPR) Kabupaten Nganjuk menerima.

Berdasarkan hasil uji parsial (uji t) untuk variabel dalam kontroling pekerjaan memperoleh $\mathrm{t}$ sepadan dengan 8,727 dengan nilai itu signifikansi 0,000 sebab nilai signifikansi jauh lebih kecil dari 0,05 karenanya Ho menolak, perihal ini menunjukkan bahwa $\mathrm{Ha}$ yang membunyikan ke sana adalah pengaruh yang kontroling pekerjaan ke capaian karyawan Dinas Pekerjaan Umum dan Ruang (PUPR) tentang Kabupaten Nganjuk menerima.

Koefisien Determinasi

Berdasarkan tabel di atas diketahui bahwa nilai Correlations Partial dari variabel disiplin kerja sebesar 0,297 dan variabel kontroling kerja sebesar 0,712, sehingga besarnya pengaruh $\left(\mathrm{R}^{2}\right)$ disiplin kerja terhadap kinerja karyawan adalah $(0,297)^{2}=0,088$ atau $8,8 \%$, sedangkan besarnya pengaruh kontroling kerja terhadap kinerja karyawan adalah $(0,712)^{2}=0,5069$ atau 50,69\%.

\section{Kesimpulan}

a. Terdapat pengaruh secara parsial antara disiplin kerja terhadap kinerja karyawan di Dinas Pekerjaan Umum dan Penataan Ruang (PUPR) Kabupaten Nganjuk.

b. Terdapat pengaruh secara parsial antara kontroling kerja terhadap kinerja karyawan di Dinas Pekerjaan Umum dan Penataan Ruang (PUPR) Kabupaten Nganjuk.

c. Terdapat pengaruh secara simultan antara disiplin kerja dan kontroling kerja terhadap kinerja karyawan di Dinas Pekerjaan Umum dan Penataan Ruang (PUPR) Kabupaten Nganjuk, sedangkan sisanya dipengaruhi oleh faktor lain yang tidak dikaji dalam penelitian ini.
Perbedaan penelitian ini dengan penelitian sebelumnya adalah mempertimbangkan variabel-variabel lain di luar variabel yang sudah masuk dalam penelitian sebelumnya, yaitu variabel disiplin kerja, kontroling kerja, dan kinerja karyawan yang saling berkaitan.

\section{Daftar Pustaka}

Ali, Muhammad. (2017), Kependidikan Prosedur dan Strategi. Bandung: Angkasa.

Arikunto, Suharsimi. (2016), Prosedur Penelitian Suatu Pendekatan Praktek. Jakarta: Rineka Cipta.

Fahmi, Irfan. (2013), Manajemen Kepemimpinan: Teori dan Aplikasi, Bandung: Alfabeta.

Fais, Satrianegara. (2013), Pengembangan Manajemen Sumber Daya Manusia. Makasar: Alauddin University Press.

Fathoni, Abdurrahmat. (2016), Organisasi dan Manajemen Sumber Daya Manusia. Jakarta: Rineka Cipta.

Ghozali, Imam. (2016), Aplikasi Analisis Multivariate Dengan Program SPSS. Semarang: Badan Penerbit Universitas Diponegoro.

Handoko, T. Hani. (2016), Manajemen Personalia Dan Sumber Daya Manusia. Yogyakarta: BPFE.

Hasibuan, Malayu. (2015), Menejemen Sumber Daya Manusia. Jakarta: Bumi Aksara.

Mangkunegara, Anwar Prabu. (2014), Manajemen Sumber Daya Manusia Strategik. Jakarta: Ghalia Indonesia.

Mangkuprawira, Sjafri dan Aida Vitayala Hubeis. (2012) Manajemen Mutu Sumber Daya Manusia, Bogor: Ghalia Indonesia.

Mathis, Robert L. dan John H. Jackson. (2016) Manajemen Sumber Daya Manusia, Jakarta: Salemba Empat.

Nawawi. (2012), Kepemimpinan Mengefektifkan Organisasi. Jakarta: Erlangga.

Prawirosentono, Suyadi. (2012), Manajemen Sumberdaya Manusia: Kebijakan Kinerja Karyawan Kiat Membangun Organisasi Kompetitif Menjelang Perdagangan Bebas Dunia, Yogyakarta: BPFE.

Rifa'i, Vheital dan Ella Jauvani Sagala. (2015), Menejemen Sumber Daya 
Manusia Untuk Perusahaan. Jakarta:

Raja Grafido Persada.

Robbins, James G. dan Barbara S. Jones. (2012), Komunikasi Organisasi Teori dan Studi Kasus. Jakarta: Mandar Maju.

Satrohadiwiyo. (2011), Sumber Daya Manusia dan Produktivitas Kerja. Bandung: CV. Mandar Maju.

Siagian, Sondang. P. (2015), Manajemen Sumber Daya Manusia.Jakarta: Penerbit Bumi Aksara.

Simamora. (2014), Manajemen Sumber Daya Manusia. Yogyakarta: STIE, YKPN.

Siswanto, Bejo. (2013), Manajemen Tenaga Kerja Indonesia, Pendekatan Administratif dan Operasional. Jakarta: Bumi Aksara.

Sugiyono. (2014), Metode Penelitian Kuantitatif, Kualitatif dan $\mathrm{R} \& \mathrm{D}$.
Cetakan ke-17. CV. Alfabeta, Bandung.

Sutrisno, Edy. (2015), Manajemen Sumber Daya Manusia. Jakarta. Kencana Prenada Media Group.

Triyaningsih, Retno. (2012), Pengarub Kepemimpinan dan Motivasi terhadap Kinerja Karyawan, Semarang: Unnes Press.

Umam, Khaerul. (2015), Perilaku Organisasi. Bandung: Pustaka Setia.

Umar, Husein. (2015), Riset Sumber Daya Manusia dalam Organisasi. Jakarta: Gramedia Pustaka Utama.

Vebiyanti, Helen. (2014), Hubungan Persepsi Karyawan terhadap Kepemimpinan dan Lingkungan Kerja, Yogyakarta: Universitas Sanata Dharma. 